Original Article

\title{
Quercetin-induced apoptosis ameliorates vascular smooth muscle cell senescence through AMP-activated protein kinase signaling pathway
}

\author{
Seul Gi Kim ${ }^{1,3}$, Jin Young Sung ${ }^{1,3}$, Jae-Ryong Kim ${ }^{2,3}$, and Hyoung Chul Choi ${ }^{13, *}$ \\ ${ }^{1}$ Department of Pharmacology, ${ }^{2}$ Department of Biochemistry and Molecular Biology, ${ }^{3}$ Smart-aging Convergence Research Center, Yeungnam University \\ College of Medicine, Daegu 42415, Korea
}

\section{ARTICLE INFO}

Received August 16, 2019

Revised October 22, 2019

Accepted October 22, 2019

*Correspondence

Hyoung Chul Choi

E-mail: hcchoi@med.yu.ac.kr

\section{Key Words}

Aging

AMP-activated protein kinase

Apoptosis

Quercetin

Vascular smooth muscle cell
ABSTRACT Aging is one of the risk factors for the development of cardiovascular diseases. During the progression of cellular senescence, cells enter a state of irreversible growth arrest and display resistance to apoptosis. As a flavonoid, quercetin induces apoptosis in various cells. Accordingly, we investigated the relationship between quercetin-induced apoptosis and the inhibition of cellular senescence, and determined the mechanism of oxidative stress-induced vascular smooth muscle cell (VSMC) senescence. In cultured VSMCs, hydrogen peroxide $\left(\mathrm{H}_{2} \mathrm{O}_{2}\right)$ dose-dependently induced senescence, which was associated with increased numbers of senescenceassociated $\beta$-galactosidase-positive cells, decreased expression of SMP30, and activation of p53-p21 and p16 pathways. Along with senescence, expression of the antiapoptotic protein $\mathrm{Bcl}-2$ was observed to increase and the levels of proteins related to the apoptosis pathway were observed to decrease. Quercetin induced apoptosis through the activation of AMP-activated protein kinase. This action led to the alleviation of oxidative stress-induced VSMC senescence. Furthermore, the inhibition of AMPK activation with compound $C$ and siRNA inhibited apoptosis and aggravated VSMC senescence by reversing p53-p21 and p16 pathways. These results suggest that senescent VSMCs are resistant to apoptosis and quercetin-induced apoptosis attenuated the oxidative stress-induced senescence through activation of AMPK. Therefore, induction of apoptosis by polyphenols such as quercetin may be worthy of attention for its anti-aging effects.

\section{INTRODUCTION}

Aging is a physiological phenomenon observed in all eukaryotes. The risk factors for cardiovascular diseases such as hypertension and arteriosclerosis are observed to increase with age [1]. The fundamental mechanism of aging is related to the process of cellular senescence. While senescent cells are observed to be in a state of irreversible growth arrest, they remain metabolically active. This cellular senescence is caused by loss of telomere function and oxidative stresses, such as hydrogen peroxide $\left(\mathrm{H}_{2} \mathrm{O}_{2}\right)$, genetic toxicity, and oncogene activation [2,3]. Senescent cells are characterized by changes in cell morphology, DNA damage, cell cycle arrest, increased senescence-associated $\beta$-galactosidase (SA$\beta$-gal) activity, and resistance to apoptosis $[3,4]$.

Apoptosis, called programmed cell death, is the active process of self-destruction as a means of defense against stressful stimuli. In continuous stresses such as aging, the suppression of apoptosis can affect cell survival because cells will not maintain homeostasis [5,6]. It has been initially suggested in 1995 that senescent cells have resistance to apoptosis and that the $\mathrm{Bcl}-2$ protein is involved (i) \$ This is an Open Access article distributed under the terms of the Creative Commons Attribution Non-Commercial License, which permits unrestricted non-commercial use, distribution, and reproduction in any medium, provided the original work is properly cited. Copyright @ Korean J Physiol Pharmacol, pISSN 1226-4512, elSSN 2093-3827
Author contributions: S.G.K. performed the experiments and wrote the paper. J.Y.S. analyzed data and discussed manuscript. J.R.K. supervised the project. H.C.C. conceived and designed the experiments. 
in this effect [7]. Previous studies have reported that senescent human keratinocytes are relatively resistant to UV-induced apoptosis compared to young keratinocytes [8]. Additionally, it was reported that in human fibroblasts, the failure of stress-induced downregulation of $\mathrm{Bcl}-2$ caused the resistance of senescent fibroblasts to apoptosis [9].

AMPK plays a key role in the energy homeostasis [10]. It has been demonstrated that AMPK is associated with aging [11,12]. The activation of AMPK pathway ameliorated aging-related vascular endothelial dysfunction in aged rats [13]. Moreover, the induction of autophagy through the LKB1-AMPK signaling pathway inhibited senescence in VSMCs [14].

According to various studies, the mortality rates due to cardiovascular diseases are improved by a diet with high consumption of fruits and vegetables. This is attributed to the polyphenols that are present in these foods [15]. Quercetin is a flavonoid that belongs to the group of polyphenols, found mainly in apples, grapes, berries, and red wine [16]. It is widely known that quercetin displays not only an inhibitory effect against proliferation but also anti-cancer, anti-inflammatory, and anti-oxidative activities [1618]. In breast cancer cells, quercetin regulated apoptosis and cell cycle arrest [19]. Additionally, several studies have indicated that the quercetin-induced AMPK signaling pathway induced apoptosis in several cancer cells [20-22].

Although quercetin induced apoptosis in VSMCs [23], the mechanisms are yet to be elucidated. Also, the fundamental inhibitory mechanism of senescence in VSMCs has not yet been demonstrated. We focused on the resistance to apoptosis by senescent cells in this study. Thus, we investigated whether this resistance occurs in VSMC senescence and whether quercetininduced apoptosis can inhibit VSMC senescence through AMPK activation.

\section{METHODS}

\section{Reagents and antibodies}

Quercetin and $\mathrm{H}_{2} \mathrm{O}_{2}$ were purchased from Sigma-Aldrich (St. Louis, MO, USA). Antibodies against p-LKB1, AMPK, p-AMPK, p-acetyl CoA carboxylase (ACC), p53, Bax, cytochrome C, caspase-3, and cleaved caspase- 3 were purchased from Cell Signaling Technology (Beverly, MA, USA). Antibodies against p21, p16, Bcl2, SMP30 and actin were purchased from Santa Cruz Biotechnology (Santa Cruz, CA, USA) and anti-Bcl-2 was purchased from GeneTex (Irvine, CA, USA). Compound C, an AMPK inhibitor, was provided by Calbiochem (La Jolla, CA, USA). Control and AMPK siRNA were purchased from Santa Cruz Biotechnology.

\section{Primary cell culture}

Sprague-Dawley rats were euthanized with $95 \% \mathrm{CO}_{2}$ and then the thoracic aorta was isolated. The isolated aorta was placed in a $10-\mathrm{cm}$ dish with serum-free DMEM and removed fat tissue and adventitia. The aorta was longitudinally cut, and the lumen side was scraped with cotton swab to eliminate the intima. After the aorta was cut into 3-5 mm pieces, these pieces explanted lumen side down on a new $10-\mathrm{cm}$ dish with DMEM supplemented with 50\% FBS. The dish was incubated in a $\mathrm{CO}_{2}$ incubator $(5 \%$ $\mathrm{CO}_{2} / 95 \%$ air, $37^{\circ} \mathrm{C}$ ). After 3 days, aorta pieces were removed and sprouted VSMCs were collected. The primary cells were cultured in growth medium (DMEM supplemented with 10\% FBS and 1\% antibiotics) and we used VSMCs from passages 4-7 at 70\%-90\% confluence in $10-\mathrm{cm}$ dishes. Additionally, their growth was arrested by incubation in serum-free DMEM for $24 \mathrm{~h}$ prior to use.

\section{Induction of senescence and drug treatment}

To induce senescence, cells in serum-free medium were treated with different concentrations of $\mathrm{H}_{2} \mathrm{O}_{2}$ for $1 \mathrm{~h}$. After treatment, the medium was replaced with growth medium and then incubated for another $24 \mathrm{~h}$. Subsequently, cells were treated with quercetin $(50 \mu \mathrm{M})$ for $6 \mathrm{~h}$.

\section{Western blot analysis}

Whole cell extracts were prepared by lysis in a pro-prep protein extract buffer. The protein concentration was quantified with the protein assay reagent from Bio-Rad (Hercules, CA, USA). Equal amounts of protein were mixed with Laemmli Sample Buffer (Bio-Rad) and heated for $5 \mathrm{~min}$ at $95^{\circ} \mathrm{C}$ before loading. Total protein samples $(20 \mu \mathrm{g})$ were subjected to $10 \%$ SDS-polyacrylamide gel electrophoresis for $90 \mathrm{~min}$ at 100-120 V. Separated proteins were electrophoretically transferred to a PVDF membrane for $40 \mathrm{~min}$ at $100 \mathrm{~V}$. Membranes were blocked with 5\% non-fat milk in PBS containing 0.05\% Tween 20 (PBS-T) for $1 \mathrm{~h}$ at room temperature followed by incubation with the primary antibodies overnight at $4^{\circ} \mathrm{C}$ in PBS-T. Membranes were washed in PBS$\mathrm{T}$ and incubated for $1 \mathrm{~h}$ at room temperature in 5\% non-fat milk containing anti-rabbit or anti-mouse IgG (GeneTex). After washing with PBS-T, membranes were exposed to enhanced chemiluminescence (ECL) and ECL Plus western blot analysis detection reagents.

\section{Transfection of siRNA}

Transfection of VSMCs with siRNA was performed using the Lipofectamine 2000 reagent (Invitrogen, Carlsbad, CA, USA) according to the manufacturer's instructions. VSMCs were seeded on 6-well plates and grown to about $70 \%$ confluence. Cells were then transfected with $10 \mu \mathrm{M}$ control or AMPK siRNA and 100 pmol of Lipofectamine for $6 \mathrm{~h}$ in the Opti-MEM reduced-serum medium (Invitrogen). After an incubation period of $48 \mathrm{~h}$, the experiments were performed. 


\section{Cell viability}

VSMCs were seeded on 12 -well plates at $1 \times 10^{5}$ cells per well in growth media. After treatment with $\mathrm{H}_{2} \mathrm{O}_{2}, 50 \mu \mathrm{l}$ of $1 \mathrm{mg} / \mathrm{ml}$ MTT solution was added to each well $(0.1 \mathrm{mg} /$ well $)$ and incubated for 4 h. Supernatants were aspirated and the formazan crystals in each well were solubilized with $200 \mu \mathrm{l}$ of dimethyl sulfoxide (DMSO). Aliquots $(100 \mu \mathrm{l})$ were placed in 96-well plates. Cell viability was assessed by measuring the absorbance at $570 \mathrm{~nm}$ using a microplate reader.
A<smiles>O=c1c(O)c(-c2ccc(O)c(O)c2)oc2cc(O)cc(O)c12</smiles>

Quercetin

C
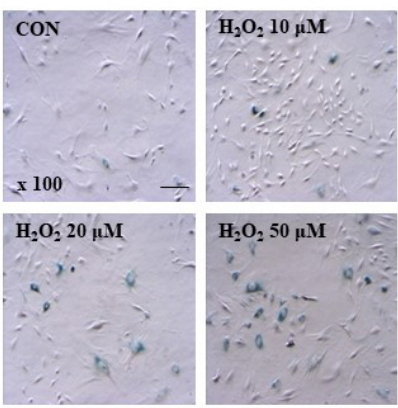

\section{SMP30}

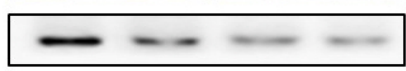

Actin
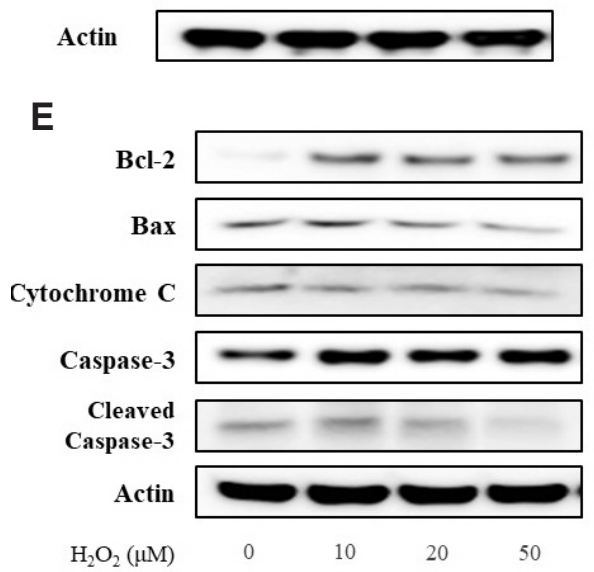

\section{SA- $\beta$-gal staining}

SA- $\beta$-gal staining was performed using a senescence $\beta$-galactosidase staining kit (Cell Signaling Technology). Briefly, VSMCs $\left(1 \times 10^{5}\right)$ were seeded on 6-well plates and fixed for $1 \mathrm{~h}$ at room temperature. The cells were then washed with PBS, followed by incubation with staining solutions and $\mathrm{X}$-gal $(20 \mathrm{mg} / \mathrm{ml})$ for $16-17 \mathrm{~h}$ at $37^{\circ} \mathrm{C}\left(\right.$ no $\left.\mathrm{CO}_{2}\right)$.

\section{B}

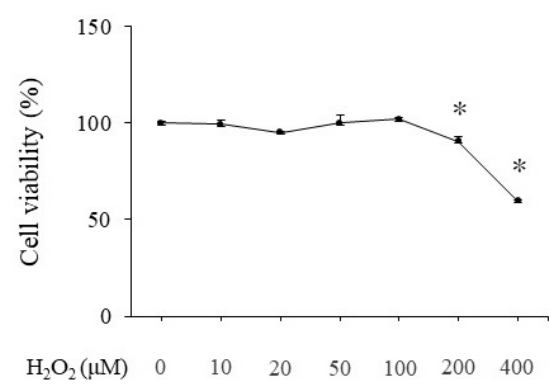

D
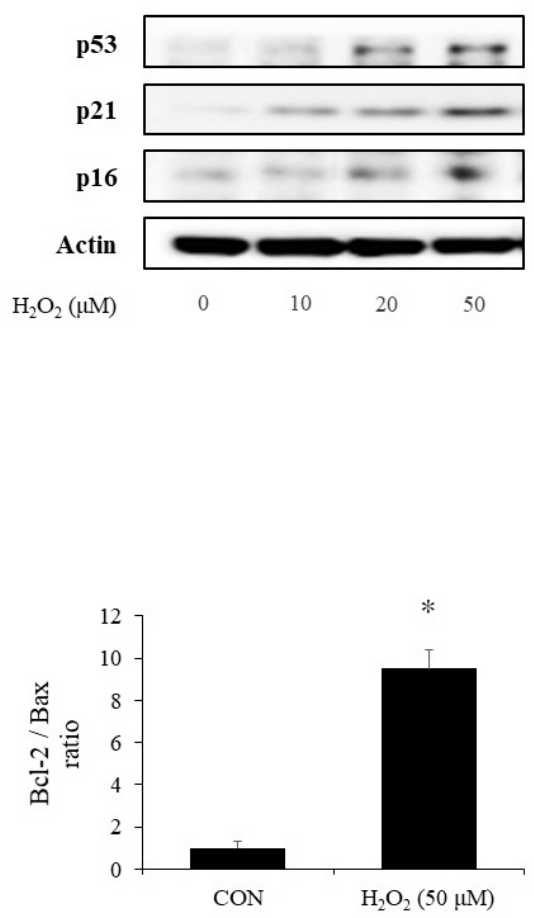

Fig. 1. Induction of senescence in vascular smooth muscle cells by hydrogen peroxide $\left(\mathrm{H}_{2} \mathrm{O}_{2}\right)$. (A) The chemical structure of quercetin. (B) Cells were incubated with different concentrations of $\mathrm{H}_{2} \mathrm{O}_{2}$ for $1 \mathrm{~h}$. The cell viability was examined by MTT assay. (C) The cells stained with senescence-associated $\beta$-galactosidase and the expression of SMP30 was determined by western blot analysis to evaluate the senescent status (scale bar $=100 \mu \mathrm{M}$ ). (D) Results of western blot analysis indicate that the $\mathrm{H}_{2} \mathrm{O}_{2}$ treatment induced p53-p21 and p16 expressions. (E) $\mathrm{H}_{2} \mathrm{O}_{2}$-induced senescent cells displayed resistance to apoptosis by increasing $\mathrm{Bcl}-2$ expression and inhibiting the apoptosis pathway. Representative results from three independent experiments are shown $(n=3) ;{ }^{*} p<0.05$ vs. control. 


\section{Apoptosis analysis}

Apoptosis was examined by Annexin V-fluorescein isothiocyanate (FITC) staining (BD Biosciences, San Jose, CA, USA). After seeding of VSMCs $\left(3 \times 10^{5}\right)$ on 6-well plates, cells were treated with $\mathrm{H}_{2} \mathrm{O}_{2}$, quercetin and/or compound C. The FITC fluorescence intensity of 10,000 cells was measured using a BectonDickinson FACS Caliber flow cytometer (BD Biosciences). Additionally, analysis by acridine orange (AO) staining was used to examine the apoptosis. Cells grown in 6-well plates were washed with PBS and then incubated with AO solution (Immuno Chemistry Technologies, Bloomington, MN, USA) for $20 \mathrm{~min}$ at $37^{\circ} \mathrm{C}$. After incubation, cells were washed with PBS and imaged under a fluorescence microscope (Olympus, Tokyo, Japan).

\section{Immunofluorescence analysis}

VSMCs were seeded on 6 -well plates at $1 \times 10^{5}$ per well, fixed in $4 \%$ formaldehyde, and permeabilized with $0.2 \%$ Triton X-100. Consequently, the cells were blocked with $5 \%$ goat serum for $1 \mathrm{~h}$,
A

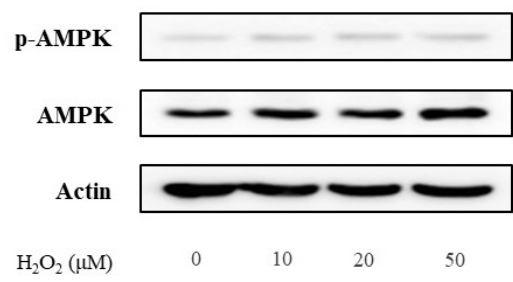

C
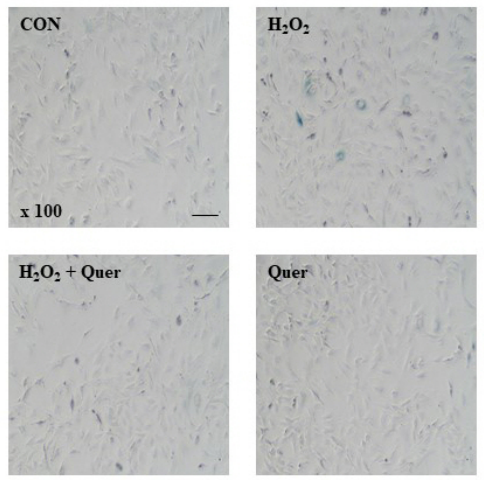

E

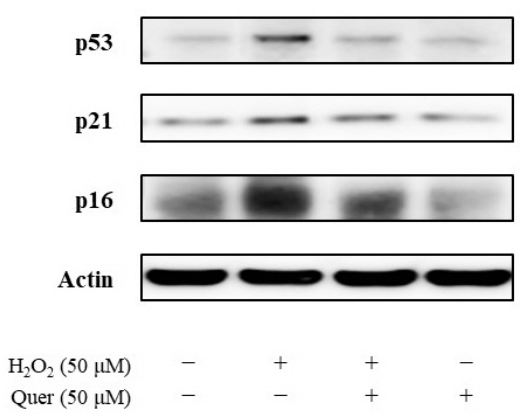

B

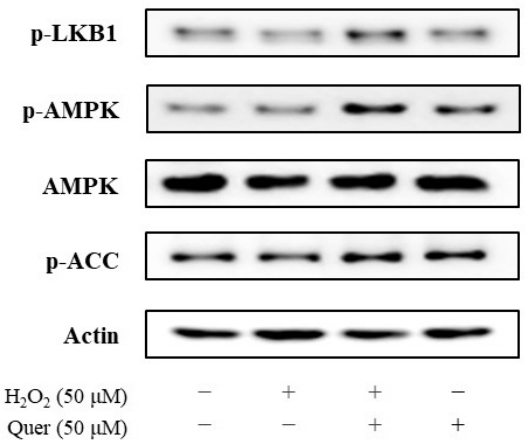

D

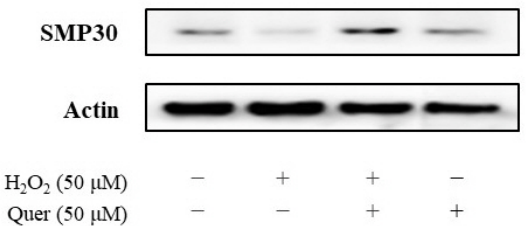

Fig. 2. The effects of quercetin on vascular smooth muscle cell (VSMC) senescence. (A) The protein level of AMPK was not changed by hydrogen peroxide $\left(\mathrm{H}_{2} \mathrm{O}_{2}\right)(10,20$, and $50 \mu \mathrm{M})$. After treatment with $\mathrm{H}_{2} \mathrm{O}_{2}(50 \mu \mathrm{M}, 1 \mathrm{~h})$, cells were incubated with quercetin $(50 \mu \mathrm{M}, 6 \mathrm{~h})$. (B) Western blot analysis indicated that quercetin induced the AMPK signaling pathway in VSMCs. (C and D) The senescence of VSMCs was observed to be delayed by quercetin (scale bar $=100 \mu \mathrm{M})$. (E) The protein levels of p53, p21, and p16 were determined by western blot analysis. Representative results from three independent experiments are shown $(n=3)$. 
followed by incubation with primary antibodies of Bax (1:500) and Bcl-2 (1:25) overnight at $4^{\circ} \mathrm{C}$. Mouse or rabbit FITC secondary antibody (Invitrogen) were used at 1:200 and incubated for $40 \mathrm{~min}$ at room temperature. After immunofluorescent staining, cells were imaged under a fluorescence microscope (Olympus).

\section{Statistical analysis}

Excel (Microsoft, Redmond, WA, USA) and GraphPad Prism (GraphPad Software, San Diego, CA, USA) were used for data acquisition and analysis. All data were expressed as mean \pm standard error of the mean from at least three independent experiments. Differences between data sets were assessed by one-way analysis of variance (ANOVA) of Bonferroni's t-test, with p-values $<0.05$ considered significant.

\section{RESULTS}

\section{$\mathrm{H}_{2} \mathrm{O}_{2}$ induces senescence and senescent cells have a resistance to apoptosis in VSMCs}

As $\mathrm{H}_{2} \mathrm{O}_{2}$ induced premature senescence or apoptosis in previous studies [24-27], we first investigated the cell viability using the MTT assay after treatment with different concentrations of $\mathrm{H}_{2} \mathrm{O}_{2}$ $(10,20,50,100,200$, and $400 \mu \mathrm{M})$. While the difference of cell viability was not observed from control to $100 \mu \mathrm{M}$, cell viability was reduced after treatment of more than $200 \mu \mathrm{M}$ with statistical significance (Fig. 1B). To confirm $\mathrm{H}_{2} \mathrm{O}_{2}$-induced senescence, we investigated the SA- $\beta$-gal activity and expression of SMP30, a senescence marker. As shown in Fig. $1 \mathrm{C}, \mathrm{H}_{2} \mathrm{O}_{2}$ treatment led to a dose-dependent increase in senescence. In addition, it was observed that p53-p21 and p16 expressions, indicators of senescent cells, were accelerated dose-dependently (Fig. 1D). Consequently, we tested whether the senescent VSMCs by $\mathrm{H}_{2} \mathrm{O}_{2}$ had a resistance to apoptosis. As VSMCs were not senescent state in control, the protein levels of Bax, cytochrome $\mathrm{C}$ and cleaved caspase-3, which are involved in the apoptosis pathway, were expressed. However,
A
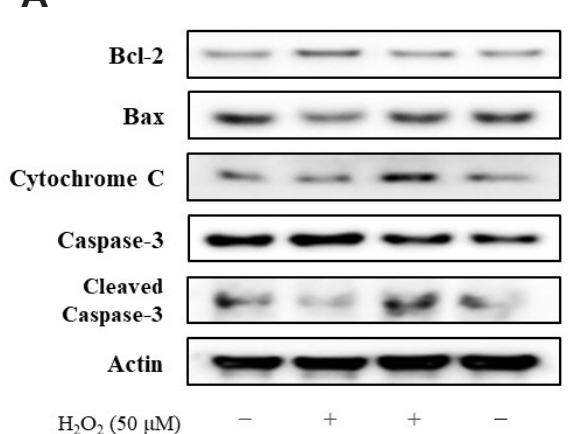
$\begin{array}{lllll}\mathrm{H}_{2} \mathrm{O}_{2}(50 \mu \mathrm{M}) & - & + & + & - \\ \text { Quer }(50 \mu \mathrm{M}) & - & - & + & +\end{array}$

C

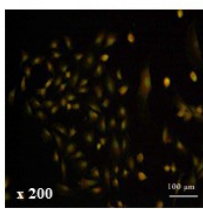

$\mathrm{H}_{2} \mathrm{O}_{2}(50 \mu \mathrm{M})$ Quer $(50 \mu \mathrm{M})$

$+$

$-$
B
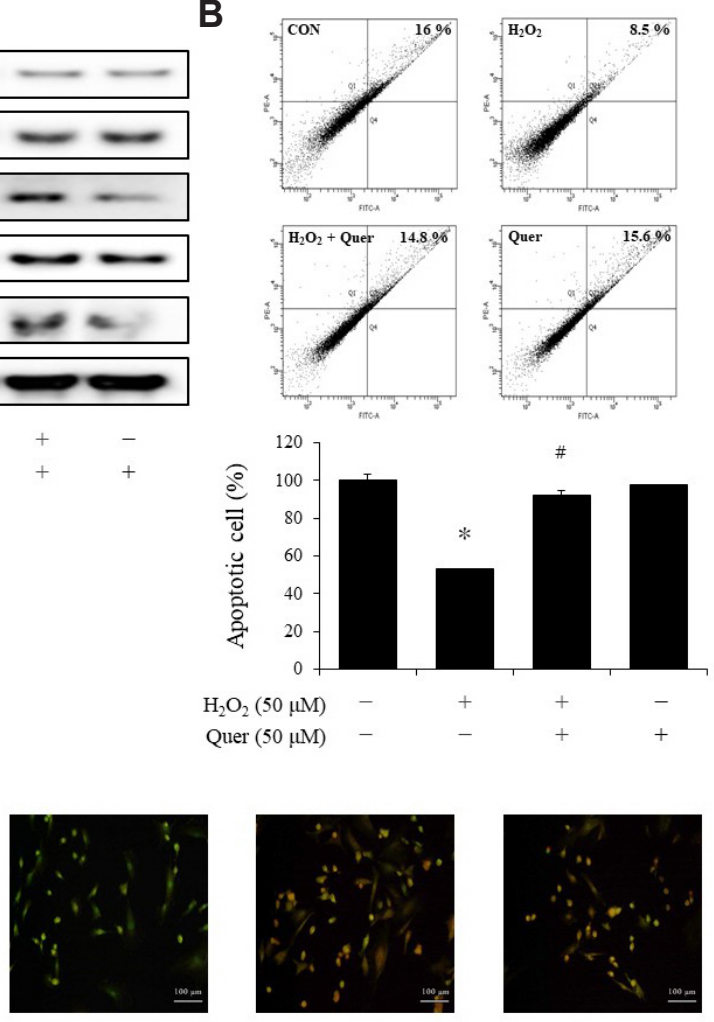
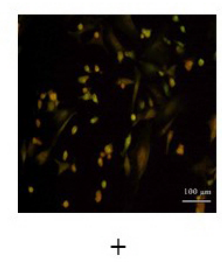

$+$

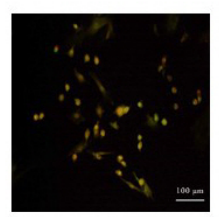

$-$

Fig. 3. The effects of quercetin on apoptosis in vascular smooth muscle cells. After treatment with hydrogen peroxide $\left(\mathrm{H}_{2} \mathrm{O}_{2}\right)(50 \mu \mathrm{M}, 1 \mathrm{~h})$, cells were incubated with quercetin $(50 \mu \mathrm{M}, 6 \mathrm{~h})$. (A) Quercetin inhibited $\mathrm{H}_{2} \mathrm{O}_{2}$-increased protein level of Bcl-2 and induced the apoptosis pathway. (B) Apoptosis was assessed with Annexin V-FITC staining by flow cytometric analysis followed by determination of the percentage of apoptotic cells. (C) The apoptotic cells were stained with acridine orange solution. Representative results from three independent experiments are shown $(n=3) ;{ }^{*} p<0.01$ vs. control, ${ }^{\sharp} \mathrm{p}<0.01$ vs. $\mathrm{H}_{2} \mathrm{O}_{2}$ alone. 
these protein levels were declined by $\mathrm{H}_{2} \mathrm{O}_{2}$ treatment. Furthermore, it was observed that the ratio of $\mathrm{Bcl}-2 / \mathrm{Bax}$ was enhanced because of an increase of anti-apoptotic protein $\mathrm{Bcl}-2$ level and a decrease of pro-apoptotic protein Bax level after $\mathrm{H}_{2} \mathrm{O}_{2}$ treatment (Fig. 1E). Based on these results, we selected $50 \mu \mathrm{M} \mathrm{H}_{2} \mathrm{O}_{2}$ as the ideal concentration to induce VSMC senescence to be used in our following experiments. Taken together, these data show that $\mathrm{H}_{2} \mathrm{O}_{2}$ induced the senescence of VSMCs and senescent VSMCs were observed to have a resistance to apoptosis.

\section{Quercetin attenuates $\mathrm{H}_{2} \mathrm{O}_{2}$-induced senescence in VSMCs}

In our previous study, we ascertained the ideal concentration and time of quercetin to activate the AMPK in VSMCs [28]. To confirm whether quercetin affected the senescence through AMPK activation in this study, we first investigated the activation of AMPK by $\mathrm{H}_{2} \mathrm{O}_{2}$ treatment. As shown in Fig. 2A, the activation of AMPK was not changed by $\mathrm{H}_{2} \mathrm{O}_{2}(10-50 \mu \mathrm{M})$, whereas quercetin $(50 \mu \mathrm{M})$ activated the LKB1-AMPK signaling pathway (Fig. $2 \mathrm{~B})$. In other words, the concentration of $\mathrm{H}_{2} \mathrm{O}_{2}(50 \mu \mathrm{M})$ we selected induced VSMC senescence without any change of AMPK. In addition, the LKB1-AMPK signaling pathway was activated by
A

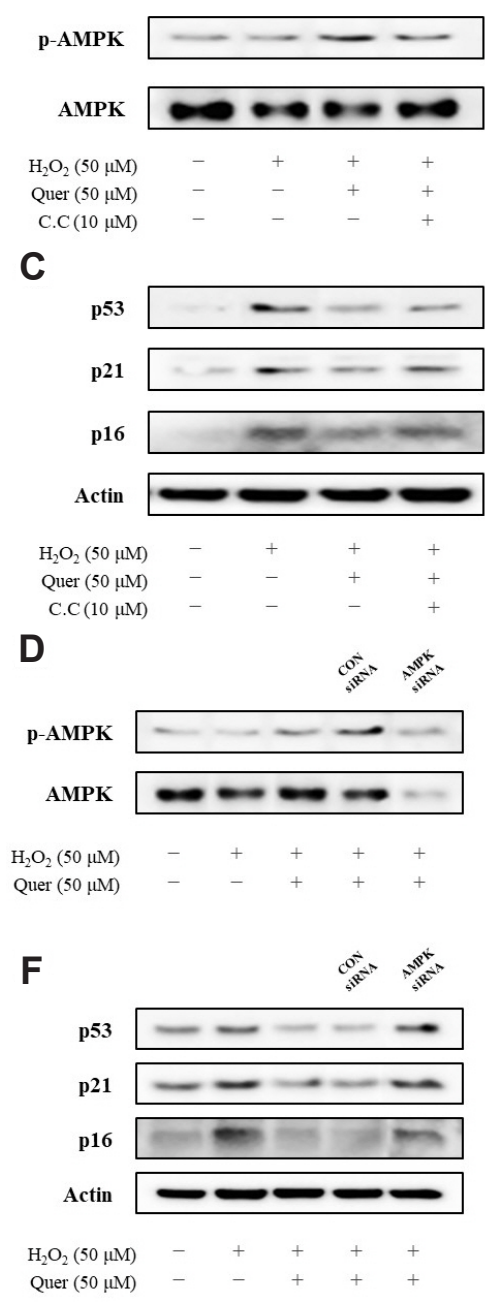

B
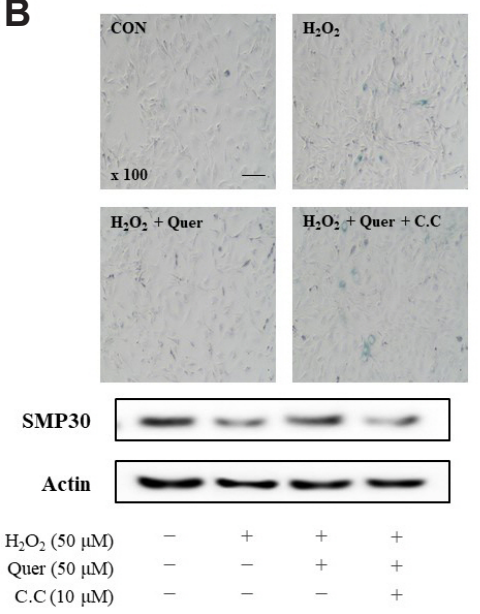

E

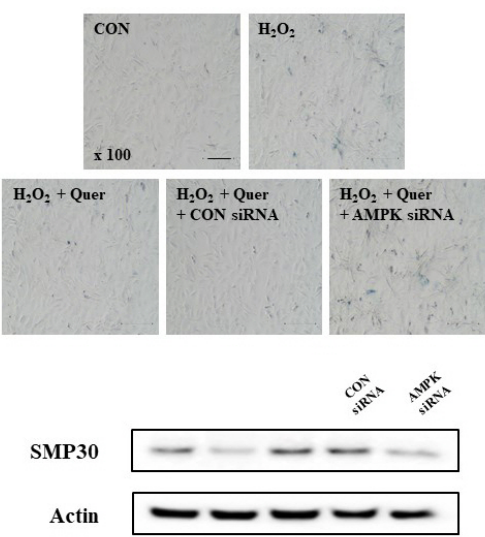

$\mathrm{H}_{2} \mathrm{O}_{2}(50 \mu \mathrm{M}) \quad-\quad+\quad+\quad++$ Quer $(50 \mu \mathrm{M}) \quad-\quad+\quad+\quad+$

Fig. 4. The inhibitory effect of quercetin-induced AMPK activation on vascular smooth muscle cell (VSMC) senescence. (A-C) Cells were incubated with quercetin $(50 \mu \mathrm{M}, 6 \mathrm{~h})$ alone or quercetin + compound $\mathrm{C}(\mathrm{C} . \mathrm{C} ; 10 \mu \mathrm{M}, 1 \mathrm{~h})$ after pretreatment with hydrogen peroxide $\left(\mathrm{H}_{2} \mathrm{O}_{2}\right)(50 \mu \mathrm{M}, 1 \mathrm{~h})$. $(\mathrm{A})$ The activation of $p$-AMPK is observed to be inhibited by C.C. (B) Senescence-associated $\beta$-galactosidase (SA- $\beta$-gal) staining and expression of SMP30 were restored by inhibiting AMPK activation. (C) The expressions of p53, p21, and p16 were determined by western blot analysis. (D-F) VSMCs were transfected with the control or AMPK siRNA for $48 \mathrm{~h}$, and incubated with $\mathrm{H}_{2} \mathrm{O}_{2}$ and quercetin. (D) VSMCs were subjected to western blot analysis to determine the level of p-AMPK. (E) After transfection, cells were stained with SA- $\beta$-gal and expression of SMP30 was confirmed. (F) Results of western blot analysis indicated that p53-p21 and p16 pathways were restored in the AMPK siRNA-transfected cells. Scale bar $=100 \mu M$. Representative results from three independent experiments are shown $(n=3)$. 
only quercetin, not $\mathrm{H}_{2} \mathrm{O}_{2}$. Subsequently, we tested the inhibitory effect of quercetin in VSMC senescence. Quercetin treatment led to a decrease in SA- $\beta$-gal activity and increase in SMP30 expression (Fig. 2C, D). As shown in Fig. 2E, $\mathrm{H}_{2} \mathrm{O}_{2}$-activated p53-p21 and 16 pathways were inhibited by quercetin.

\section{Quercetin induces apoptosis through AMPK pathway in VSMCs}

Next, we investigated the relationship of quercetin with apoptosis. Results of the western blot analysis indicated that $\mathrm{H}_{2} \mathrm{O}_{2}$ induced resistance to apoptosis, considered as a feature of senescence, was inhibited by quercetin (Fig. 3A). Besides, the result of flow cytometric analysis was consistent with that of the western blot analysis (Fig. 3B). We performed AO analysis, which dyed apoptotic cells with an orange color. The orange-colored cells were observed to be decreased by $\mathrm{H}_{2} \mathrm{O}_{2}$, but increased by quercetin (Fig. 3C). These results suggested that quercetin inhibited the $\mathrm{H}_{2} \mathrm{O}_{2}$-induced senescence by activating apoptosis in VSMCs.

\section{The inhibitory effect of AMPK activation aggravates senescence in VSMCs}

To determine whether quercetin-induced AMPK activation ameliorated cellular senescence, we treated the cells with compound $\mathrm{C}$, a chemical inhibitor of AMPK, and transfected the cells with AMPK siRNA. First, we confirmed the protein level of p-AMPK by compound C $(10 \mu \mathrm{M})$ or AMPK siRNA using western blot analysis (Fig. 4A, D), followed by investigation of SA$\beta$-gal activity and SMP30 expression. Although treatment with quercetin inhibited cellular senescence, the inhibition of AMPK increased SA- $\beta$-gal-positive cells and SMP30 expression (Fig. 4B). Additionally, quercetin-inhibited p53-p21 and p16 pathways were observed to be accelerated by compound C (Fig. 4C). Thereafter, we checked the features of senescence in AMPK siRNA-transfected cells. As shown in Fig. 4E, AMPK siRNA-transfected cells resulted in an increase in senescent cells compared with the control siRNA-transfected cells. Besides, p53-p21 and p16 pathways were observed to increase by transfection with AMPK siRNA (Fig. 4F).

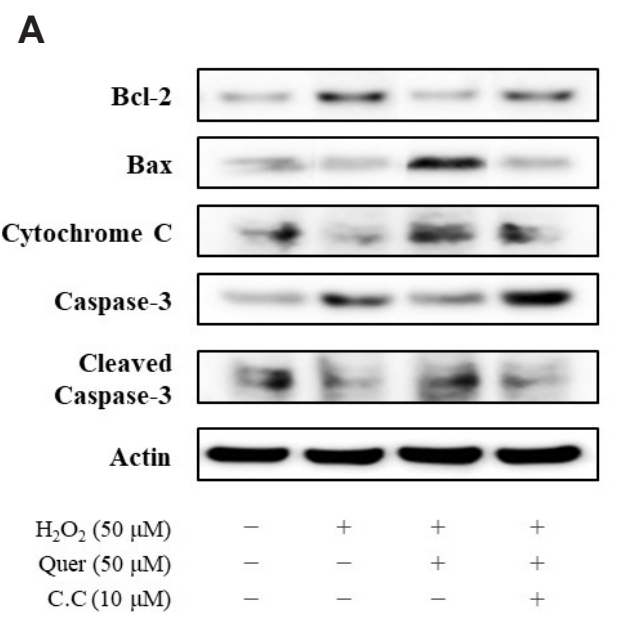

B
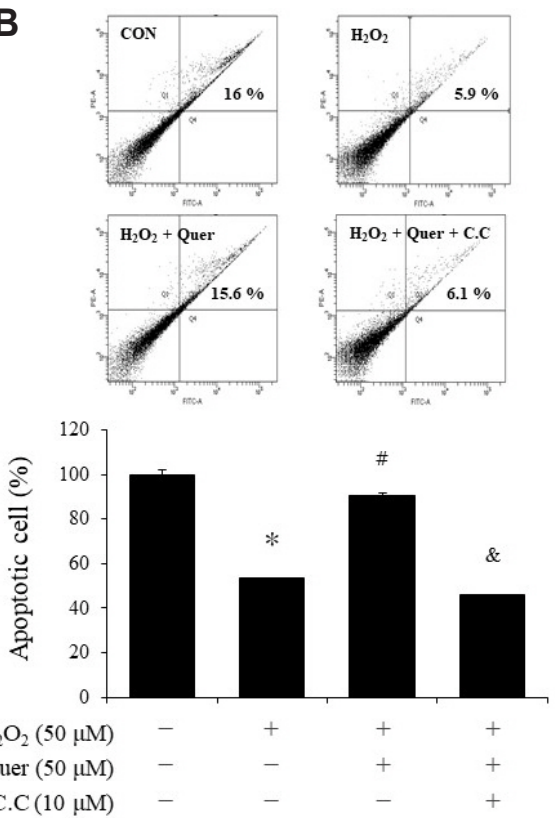

C
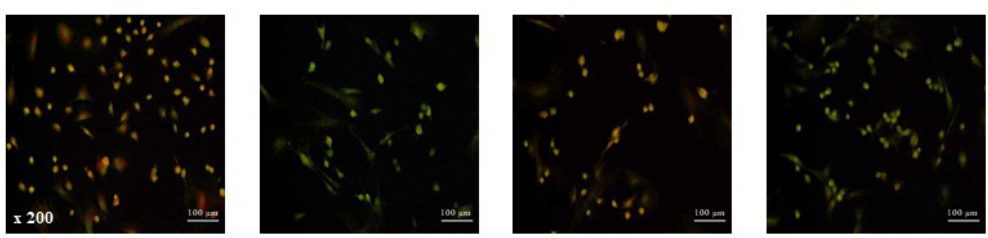

$\mathrm{H}_{2} \mathrm{O}_{2}(50 \mu \mathrm{M})$

Quer $(50 \mu \mathrm{M})$

C.C $(10 \mu \mathrm{M})$

Fig. 5. The inhibitory effect of compound C on quercetin-induced apoptosis in vascular smooth muscle cell (VSMC). Cells were incubated with quercetin $(50 \mu \mathrm{M}, 6 \mathrm{~h})$ alone or quercetin + compound C (C.C; $10 \mu \mathrm{M}, 1 \mathrm{~h})$ after pretreatment with hydrogen peroxide $\left(\mathrm{H}_{2} \mathrm{O}_{2}\right)(50 \mu \mathrm{M}, 1 \mathrm{~h})$. (A) Bcl-2 and pro-apoptotic proteins were determined by western blot analysis. (B) Results of flow cytometric analysis indicated that quercetin induced apoptosis by activating AMPK. (C) VSMCs were stained with acridine orange solution to visualize apoptotic cells. Representative results from three independent experiments are shown $(n=3) ;{ }^{*} p<0.05$ vs. control, ${ }^{*} p<0.05$ vs. $\mathrm{H}_{2} \mathrm{O}_{2}$ alone, ${ }^{\&} p<0.05$ vs. C.C. 
These results suggested that the inhibitory effect of quercetin on $\mathrm{H}_{2} \mathrm{O}_{2}$-induced senescence is regulated through AMPK activation in VSMCs.

\section{Quercetin induces apoptosis through the AMPK signaling pathway in senescent VSMCs}

We tested the possibility of whether quercetin-induced apoptosis inhibited cellular senescence by AMPK activation, when senescent cells show resistance to apoptosis. We first confirmed the levels of protein related to apoptosis using western blot analysis.
Quercetin decreased $\mathrm{H}_{2} \mathrm{O}_{2}$-activated Bcl-2 levels and increased the amount of apoptosis. However, compound $\mathrm{C}$ inhibited the apoptosis pathway (Fig. 5A). The result of flow cytometric analysis corresponded with that of the western blot analysis (Fig. 5B). To visualize the apoptotic cells, we performed AO staining. As expected, the inhibition of AMPK reduced the amount of orangestained cells compared to co-treatment with $\mathrm{H}_{2} \mathrm{O}_{2}$ and quercetin (Fig. 5C).
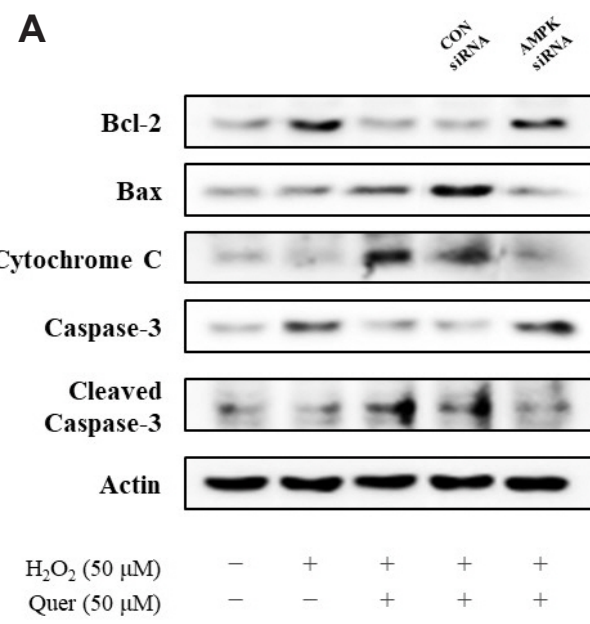

C
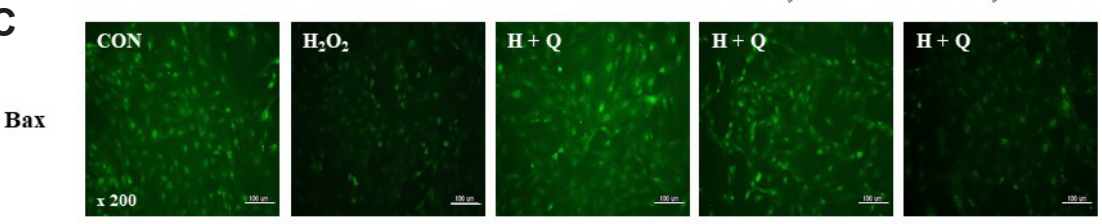

Bcl-2
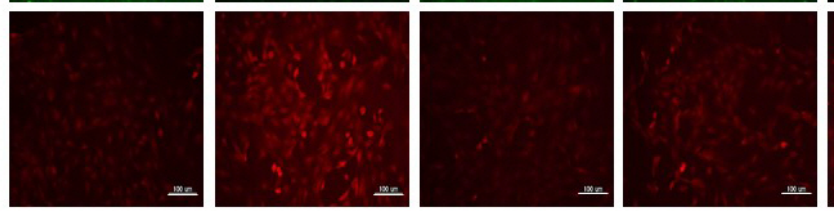

D
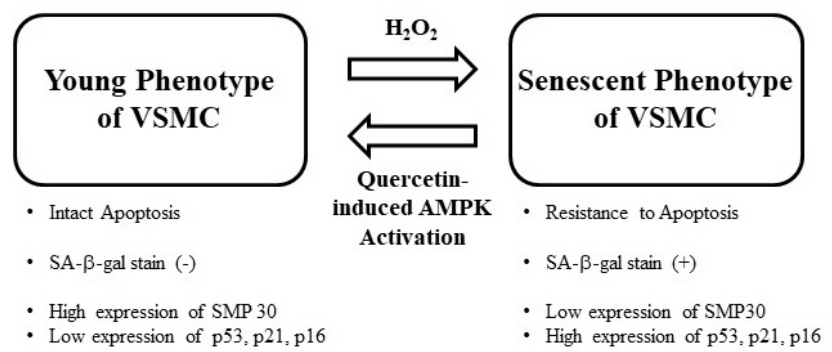

Fig. 6. The inhibitory effect of AMPK siRNA transfection on quercetininduced apoptosis in vascular smooth muscle cell (VSMC). VSMCs were transfected with control or AMPK siRNA for $48 \mathrm{~h}$ and incubated with hydrogen peroxide $\left(\mathrm{H}_{2} \mathrm{O}_{2}\right)$ and quercetin. (A) The protein levels of $\mathrm{BCl}-2, \mathrm{Bax}$, cytochrome C, Caspase- 3 and cleaved caspase- 3 were determined by western blot analysis. (B) Apoptosis was confirmed by flow cytometric analysis followed by indication of the percentage of apoptotic cells. (C) Transfected cells stained with antiBax (green) and anti-Bcl-2 (red). VSMCs transfected with AMPK siRNA showed lower Bax expression and higher Bcl2 expression. (D) The graphic abstract of quercetin-induced anti-senescence mechanism. Representative results from three independent experiments are shown $(\mathrm{n}=3) ;{ }^{*} \mathrm{p}<0.05$ vs. control, ${ }^{*} \mathrm{p}$ $<0.05$ vs. $\mathrm{H}_{2} \mathrm{O}_{2}$ alone, ${ }^{\&} \mathrm{p}<0.05$ vs. $\mathrm{CON}$ siRNA. 


\section{Genetic inhibition of AMPK decreases quercetin- induced apoptosis in VSMCs}

After transfection, we investigated the protein levels associated with the apoptosis pathway. Transfection with AMPK siRNA resulted in increased Bcl-2 expression and decreased expression of apoptotic proteins compared with the control siRNA-transfected cells (Fig. 6A). The result of flow cytometric analysis was similar to that of western blot analysis (Fig. 6B). Finally, the transfected cells were stained with anti-Bax (green) and anti-Bcl-2 (red). Compared to the treatment with $\mathrm{H}_{2} \mathrm{O}_{2}$ alone, Bax expression increased and Bcl-2 expression decreased by co-treatment with $\mathrm{H}_{2} \mathrm{O}_{2}$ and quercetin. In contrast, transfection with AMPK siRNA led to an inhibition of Bax expression and an increase of Bcl2 expression (Fig. 6C). Taken together, these results suggested that quercetin regulated $\mathrm{H}_{2} \mathrm{O}_{2}$-induced resistance to apoptosis through AMPK activation in VSMCs.

\section{DISCUSSION}

Aging is one of the major causes of cellular senescence. It is established that VSMCs in atherosclerotic plaque age faster than normal vascular cells. Previous studies have supported the fact that the senescence of vascular cells plays a central role in agerelated vascular disorders $[29,30]$. Previous studies showed that AMPK activation is associated with the life span of mammals. In keratinocytes, AMPK activation was observed to prevent oxidative stress-induced senescence [24,31]. Moreover, metformin and berberine (AMPK activators) exerted an anti-senescence effect by inducing autophagy and restoring $\mathrm{NAD}^{+}$synthesis in fibroblasts and HUVECs [32].

Polyphenols have been well known as compounds exerting physiological effects, such as anti-inflammatory, anti-cancer, and vascular reactivity. In previous studies, it has been proved that polyphenols inhibit the inflammation of adipocytes by regulating the activity of AMPK and SIRT1 [33]. Moreover, we have identified that the quercetin-induced LKB1-AMPK signaling pathway had an influence on the vasomotor effect in VSMCs [28]. Therefore, on the basis of our previous study, we investigated the effect of AMPK activation by quercetin on VSMC senescence.

According to the paper by Kirkland, as senescent cells contribute to the resistance to apoptosis, it is proposed that killing of senescent cells could enhance the life span. Moreover, they demonstrated that quercetin induced apoptosis by reduction in the expression of anti-apoptotic regulators, leading to the suppression of senescence $[34,35]$. Similarly, our results showed that senescent VSMCs by oxidative stress are resistant to apoptosis and quercetin plays a major role in delaying cellular senescence. Besides, previous studies demonstrated that the polyphenol curcumin attenuated aging-related cerebro-vascular dysfunction through the AMPK-UCP2 pathway [36] and polyphenol extracts prevented the senescence of VSMCs [37]. Although the effect of quercetin as a senolytic agent has been investigated in other studies, the underlying mechanism of the anti-aging effect of quercetin is not well-known. Therefore, we hypothesized that since senescent cells have a resistance to apoptosis, quercetin-induced apoptosis can ameliorate cellular senescence through the AMPK-dependent pathway in VSMCs.

In this study, there are several key results. First, to simulate the senescence of VSMCs, we had cells undergo oxidative stress by $\mathrm{H}_{2} \mathrm{O}_{2}$. The treatment of $\mathrm{H}_{2} \mathrm{O}_{2}(50 \mu \mathrm{M})$ induced the senescence without variation of the cell viability in VSMCs. Additionally, we confirmed that when VSMC senescence was induced by $\mathrm{H}_{2} \mathrm{O}_{2}$, the ratio of $\mathrm{Bcl}-2 / \mathrm{Bax}$ was increased, leading to the suppression of apoptosis (Fig. 1). Second, quercetin decreased senescence-related phenotypes and promoted apoptosis (Figs. 2 and 3). Third, quercetin-inhibited senescence was caused by AMPK activation (Fig. 4). Furthermore, quercetin-induced apoptosis through activation of AMPK was involved in inhibition of VSMC senescence (Figs. 5 and 6).

In conclusion, our data indicate that there is a resistance to apoptosis due to senescence in VSMCs. Moreover, quercetininduced apoptosis can regulate senescence of VSMCs through AMPK activation. This study also supports the preventive or therapeutic effect of quercetin against VSMC senescence that cause cardiovascular diseases such as atherosclerosis and hypertension.

\section{ACKNOWLEDGEMENTS}

This work was supported by the Medical Research Center Program (2015R1A5A2009124) through the National Research Foundation of Korea (NRF) funded by the Ministry of Science, ICT and Future Planning.

\section{CONFLICTS OF INTEREST}

The authors declare no conflicts of interest.

\section{REFERENCES}

1. Lakatta EG, Levy D. Arterial and cardiac aging: major shareholders in cardiovascular disease enterprises: part I: aging arteries: a "set up" for vascular disease. Circulation. 2003;107:139-146.

2. von Zglinicki T, Petrie J, Kirkwood TB. Telomere-driven replicative senescence is a stress response. Nat Biotechnol. 2003;21:229-230.

3. Toussaint O, Medrano EE, von Zglinicki T. Cellular and molecular mechanisms of stress-induced premature senescence (SIPS) of human diploid fibroblasts and melanocytes. Exp Gerontol. 2000; 35:927-945.

4. Dimri GP, Lee X, Basile G, Acosta M, Scott G, Roskelley C, Medra- 
no EE, Linskens M, Rubelj I, Pereira-Smith O, Peacocke M, Campisi J. A biomarker that identifies senescent human cells in culture and in aging skin in vivo. Proc Natl Acad Sci U S A. 1995;92:9363-9367.

5. Salminen A, Ojala J, Kaarniranta K. Apoptosis and aging: increased resistance to apoptosis enhances the aging process. Cell Mol Life Sci. 2011;68:1021-1031.

6. Migliaccio E, Giorgio M, Mele S, Pelicci G, Reboldi P, Pandolfi PP, Lanfrancone L, Pelicci PG. The p66shc adaptor protein controls oxidative stress response and life span in mammals. Nature. 1999; 402:309-313.

7. Wang E. Senescent human fibroblasts resist programmed cell death, and failure to suppress bcl2 is involved. Cancer Res. 1995;55:22842292.

8. Chaturvedi V, Qin JZ, Stennett L, Choubey D, Nickoloff BJ. Resistance to UV-induced apoptosis in human keratinocytes during accelerated senescence is associated with functional inactivation of p53. J Cell Physiol. 2004;198:100-109.

9. Ryu SJ, Oh YS, Park SC. Failure of stress-induced downregulation of Bcl-2 contributes to apoptosis resistance in senescent human diploid fibroblasts. Cell Death Differ. 2007;14:1020-1028.

10. Grahame Hardie D. AMP-activated protein kinase: a key regulator of energy balance with many roles in human disease. J Intern Med. 2014;276:543-559.

11. Apfeld J, O'Connor G, McDonagh T, DiStefano PS, Curtis R. The AMP-activated protein kinase AAK-2 links energy levels and insulin-like signals to lifespan in C. elegans. Genes Dev. 2004;18:30043009.

12. Stenesen D, Suh JM, Seo J, Yu K, Lee KS, Kim JS, Min KJ, Graff JM. Adenosine nucleotide biosynthesis and AMPK regulate adult life span and mediate the longevity benefit of caloric restriction in flies. Cell Metab. 2013;17:101-112.

13. Lakshmanan AP, Watanabe K, Thandavarayan RA, Sari FR, Meilei H, Soetikno V, Arumugam S, Giridharan VV, Suzuki K, Kodama M. Curcumin attenuates hyperglycaemia-mediated AMPK activation and oxidative stress in cerebrum of streptozotocin-induced diabetic rat. Free Radic Res. 2011;45:788-795.

14. Lee KY, Kim JR, Choi HC. Genistein-induced LKB1-AMPK activation inhibits senescence of VSMC through autophagy induction. Vascul Pharmacol. 2016;81:75-82.

15. Peterson JJ, Dwyer JT, Jacques PF, McCullough ML. Associations between flavonoids and cardiovascular disease incidence or mortality in European and US populations. Nutr Rev. 2012;70:491-508.

16. Russo GL. Ins and outs of dietary phytochemicals in cancer chemoprevention. Biochem Pharmacol. 2007;74:533-544.

17. Formica JV, Regelson W. Review of the biology of quercetin and related bioflavonoids. Food Chem Toxicol. 1995;33:1061-1080.

18. Murakami A, Ashida H, Terao J. Multitargeted cancer prevention by quercetin. Cancer Lett. 2008;269:315-325.

19. Nguyen LT, Lee YH, Sharma AR, Park JB, Jagga S, Sharma G, Lee SS, Nam JS. Quercetin induces apoptosis and cell cycle arrest in triple-negative breast cancer cells through modulation of Foxo3a activity. Korean J Physiol Pharmacol. 2017;21:205-213.

20. Kim GT, Lee SH, Kim YM. Quercetin regulates sestrin 2-AMPKmTOR signaling pathway and induces apoptosis via increased intracellular ROS in HCT116 colon cancer cells. J Cancer Prev. 2013; 18:264-270.

21. Lee YK, Hwang JT, Kwon DY, Surh YJ, Park OJ. Induction of apop- tosis by quercetin is mediated through AMPKalpha1/ASK1/p38 pathway. Cancer Lett. 2010;292:228-236.

22. Su Q, Peng M, Zhang Y, Xu W, Darko KO, Tao T, Huang Y, Tao X, Yang X. Quercetin induces bladder cancer cells apoptosis by activation of AMPK signaling pathway. Am J Cancer Res. 2016;6:498-508.

23. Perez-Vizcaino F, Bishop-Bailley D, Lodi F, Duarte J, Cogolludo A, Moreno L, Bosca L, Mitchell JA, Warner TD. The flavonoid quercetin induces apoptosis and inhibits JNK activation in intimal vascular smooth muscle cells. Biochem Biophys Res Commun. 2006;346:919-925.

24. Ido Y, Duranton A, Lan F, Cacicedo JM, Chen TC, Breton L, Ruderman NB. Acute activation of AMP-activated protein kinase prevents $\mathrm{H}_{2} \mathrm{O}_{2}$-induced premature senescence in primary human keratinocytes. PLoS One. 2012;7:e35092.

25. Pu X, Yu S, Fan W, Liu L, Ma X, Ren J. Guiqi polysaccharide protects the normal human fetal lung fibroblast WI-38 cells from $\mathrm{H}_{2} \mathrm{O}_{2}$ induced premature senescence. Int J Clin Exp Pathol. 2015;8:43984407.

26. Sheng L, Jiao B, Shao L, Bi S, Cheng C, Zhang J, Jiang Y. Probucol inhibits hydrogen peroxide to induce apoptosis of vascular smooth muscle cells. Mol Med Rep. 2013;7:1185-1190.

27. Yang H, Xie Y, Yang D, Ren D. Oxidative stress-induced apoptosis in granulosa cells involves JNK, p53 and Puma. Oncotarget. 2017; 8:25310-25322.

28. Kim SG, Kim JR, Choi HC. Quercetin-induced AMP-activated protein kinase activation attenuates vasoconstriction through LKB1AMPK signaling pathway. J Med Food. 2018;21:146-153.

29. Bennett MR, Macdonald K, Chan SW, Boyle JJ, Weissberg PL. Cooperative interactions between RB and p53 regulate cell proliferation, cell senescence, and apoptosis in human vascular smooth muscle cells from atherosclerotic plaques. Circ Res. 1998;82:704-712.

30. Mercer J, Mahmoudi M, Bennett M. DNA damage, p53, apoptosis and vascular disease. Mutat Res. 2007;621:75-86.

31. Ido Y, Duranton A, Lan F, Weikel KA, Breton L, Ruderman NB. Resveratrol prevents oxidative stress-induced senescence and proliferative dysfunction by activating the AMPK-FOXO3 cascade in cultured primary human keratinocytes. PLoS One. 2015;10:e0115341.

32. Han X, Tai H, Wang X, Wang Z, Zhou J, Wei X, Ding Y, Gong H, Mo C, Zhang J, Qin J, Ma Y, Huang N, Xiang R, Xiao H. AMPK activation protects cells from oxidative stress-induced senescence via autophagic flux restoration and intracellular $\mathrm{NAD}^{+}$elevation. Aging Cell. 2016;15:416-427.

33. Xiao N, Mei F, Sun Y, Pan G, Liu B, Liu K. Quercetin, luteolin, and epigallocatechin gallate promote glucose disposal in adipocytes with regulation of AMP-activated kinase and/or sirtuin 1 activity. Planta Med. 2014;80:993-1000.

34. Zhu Y, Tchkonia T, Pirtskhalava T, Gower AC, Ding H, Giorgadze N, Palmer AK, Ikeno Y, Hubbard GB, Lenburg M, O'Hara SP, LaRusso NF, Miller JD, Roos CM, Verzosa GC, LeBrasseur NK, Wren JD, Farr JN, Khosla S, Stout MB, et al. The Achilles' heel of senescent cells: from transcriptome to senolytic drugs. Aging Cell. 2015;14:644-658.

35. Zhu Y, Tchkonia T, Fuhrmann-Stroissnigg H, Dai HM, Ling YY, Stout MB, Pirtskhalava T, Giorgadze N, Johnson KO, Giles CB, Wren JD, Niedernhofer LJ, Robbins PD, Kirkland JL. Identification of a novel senolytic agent, navitoclax, targeting the Bcl-2 family of anti-apoptotic factors. Aging Cell. 2016;15:428-435. 
36. Pu Y, Zhang H, Wang P, Zhao Y, Li Q, Wei X, Cui Y, Sun J, Shang Q, Liu D, Zhu Z. Dietary curcumin ameliorates aging-related cerebrovascular dysfunction through the AMPK/uncoupling protein 2 pathway. Cell Physiol Biochem. 2013;32:1167-1177.
37. Feresin RG, Huang J, Klarich DS, Zhao Y, Pourafshar S, Arjmandi $\mathrm{BH}$, Salazar G. Blackberry, raspberry and black raspberry polyphenol extracts attenuate angiotensin II-induced senescence in vascular smooth muscle cells. Food Funct. 2016;7:4175-4187. 